\title{
A Review Paper on Solar Greenhouse Dryer
}

\author{
Nidhi $^{1}$, Pratiksha Verma ${ }^{2}$ \\ ${ }^{1,2(}$ Mechanical Engineering Department, Maharishi Markandeshwar University, Ambala, India)
}

\begin{abstract}
Drying process is done for removing the moisture content from the product. Recently, development of greenhouse dryers, namely, solar tunnel dryer, solar tent dryer, improved solar tunnel dryer, and roof type even span solar greenhouse dryer has been studied by various researchers. In this paper, hothouse dryer below natural convection type and forced convection type are studied. Greenhouse dryer gives a very high quality product than open sun drying and it reduces the crop losses. It has been observed that use of greenhouse dryer under forced convection reduces moisture content in a very less time as well as drying rate is very fast and relative humidity is less than natural convection mode.
\end{abstract}

Keywords: Greenhouse dryer, natural convection, forced convection, food products, agricultural products.

\section{INTRODUCTION}

Greenhouse dryer is an enclosed structure having transparent walls and roofs, made up of glass, polyethylene film etc. The working phenomenon of greenhouse drying as given in fig. 1 where the product is placed in trays receiving the solar radiations through the plastic cover and moisture is removed by natural convection or forced convection. This technology improves the product quality and reduces the drying period [1].

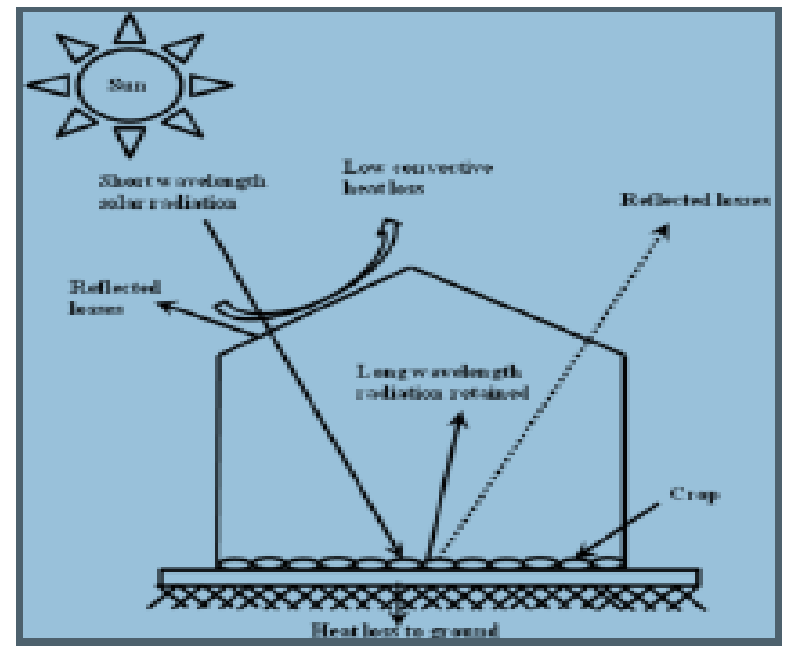

Fig. 1: Phenomenon of greenhouse drying

Taking structure as basis, greenhouse dryer is classified into two types that is dome shape and roof even type. Objective and advantage of dome and roof type greenhouse dryer is to maximize utilization of global solar radiation and is the proper mixing of air inside the dryer respectively. On the basis of heat transfer, it havingtwo types namely greenhouse dryer under passive mode (natural convection) and greenhouse dryer under active mode (forced convection) [2]. The use of greenhouse dryers is to improve the quality of the product, to prevent the infection by insects, microorganisms and bacteria, and fall of drying time interval [3].

Greenhouse dryers are constructed with a principle that they have a rigid load- bearing frame which is placed at certain spans and not deformed under the loads acting on them and a transparent cover material placed on them which allows short wave solar radiation to enter and is partially opaque to the long wave radiation leading to a greenhouse effect. Design of greenhouse should depend upon sound scientific principles that facilitates controlled 
environment for plant growth. Orientations of greenhouses are negotiate for wind direction, latitude of location and type of temperature control and avoid dropping of shadow on the nearby greenhouses. It is concluded that in the design of greenhouse, the shape and orientation of a greenhouse plays an important role [4]. Greenhouse having different shapes which as follows like spherical dome, hyperbolic paraboloid, Quonset, modified Quonset, gothic arch, mansard roof, gabic even span, gabic uneven span. Basics shapes of greenhouses of are described in fig.2 [1].

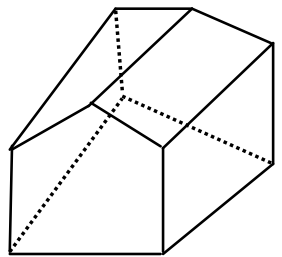

(1) Even span

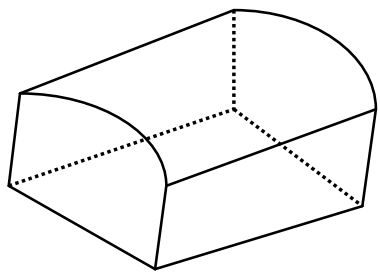

(5) Modified Quonset

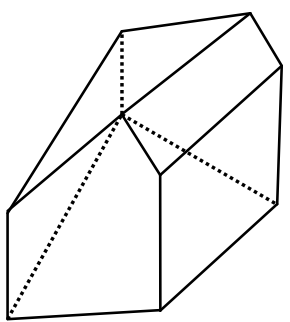

(2) Uneven span

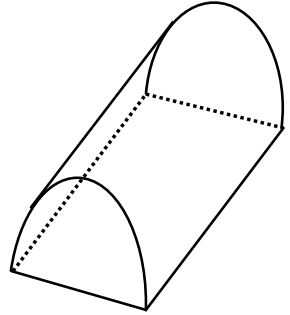

(6) Quonset

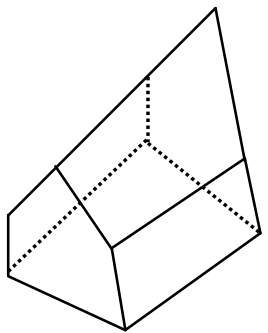

(3) Mansard roof

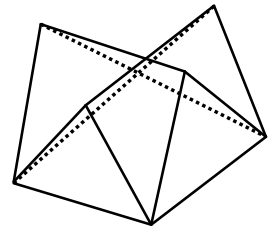

(7) Hyperbolic paraboloid

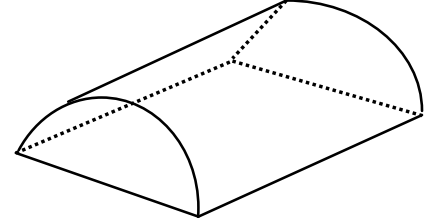

(4) Gothic arch

Fig. 1.2: Basic shapes of the greenhouses

Simple arrangement, inexpensive, appropriate for basic unit to use . Drying temperature is low and permit direct exposure to the sun's material. Solar energy drying device of glasshouse which efficiency is very low accept the solar total radiation energy efficient utilization rate is only $15 \%$ used for moisture evaporation materials, mostly lost to the atmosphere [5].

\section{LITERATURE REVIEW}

Condori and Saravia studied the efficiency of forced convection single and double chamber greenhouse drier. Results showed that double chamber greenhouse dryer is $87 \%$ more productive than single chamber for the same area. A new low cost design tunnel-type greenhouse dryer was constructed and tested [6].Wang et al. presented experimental analysis of air speed distribution in a naturally ventilated greenhouse. The result showed due to 0.837 of the regression slope the calculated air speed was lower than measured value. It concluded that average value of air speedin greenhouses is just like a key factor for calculating heat transfers between greenhouse components and interior air [7].Condori and Saravia presented an analytical study which describing the attainment of a tunnel greenhouse drier. It concluded by considering the greenhouse drier as a solar collector, an analytical linear relation is established due to which an improvement of around $160 \%$ with respect to the single chamber drier, while the improvement is of about $40 \%$ if compared with the double chamber drier [8]. Farhat et al. presented drying model of a pepper in a naturally ventilated polyethylene greenhouse. The result showed the diversity of product water loss which can be expressed as a function of ventilation rate or induced air velocity, air and product temperature and imparted solar radiation through a greenhouse cover. It concluded that the drying operation allow the exploitation of polyethylene greenhouses in summer time when not used [9].Jain and Tiwari studied of convective mass transfer coefficient and performed moisture removal rate from cabbage and peas for open sun and inside greenhouse drying. It concluded in natural mode, the convective mass transfer coefficient was lower inside the greenhouse drying as compared to open sun drying and in the initial stage of drying, its value was doubled below 
forced mode inside greenhouse drying than natural convection [10].Tiwari et al. made an attempt to check out the convective mass transfer coefficient by regression analysis during jaggery drying in the roof type even span greenhouse under natural and forced convection mode. It was found that the complete drying of jaggery under forced convection as quicker than under natural convection as expectable and convective mass transfer coefficient in forced convection was greater than in natural convection mode [11].Jain and Tiwari presented mathematical model to investigate the effect of greenhouse on crops drying (Cabbage and Peas) under natural and forced convection and for open sun drying (natural convection) [12].

Jain developed a mathematical model to study the performance of a span greenhouse with packed bed thermal storage was carried out for drying onions in trays. It was observed that the crop moisture content and drying rate decreases with the drying time of the day. This model is useful for predicting the crop temperature, moisture content and drying rate of crop and for reviewing the upgrade of crop drying by using such a greenhouse [13]. Koyuncu investigated on the performance upgrade of greenhouse type agricultural dryers. It concluded that these types of dryers are 2-5 times more effective and was of much high quality than open sun dryers and it was successfully drying a variety of agricultural products and to prevent spoilage [14]. Janjai and Chaichoet et al. investigated the performance of a PV-ventilated greenhouse dryer for drying bananas. The results showed that $50 \mathrm{~kg}$ of fresh bananas with initial moisture content of $70 \%$ can be dried in 3 days and natural sun drying required 5 days of drying time in the same weather conditions. It concluded that the dried products of high quality were acquired [15].Kumar and Tiwari studied the effect of mass on convective heat transfer coefficient during onion flakes drying. It concluded that there was 30-135\% increase in convective heat transfer as the mass of onion flakes was increased from 300 to $900 \mathrm{~g}$ for different modes of drying and it depends significantly on the mode of drying and on mass of onion to be dried [16].Kumar and Tiwari presented an experimental validation and thermal modeling of greenhouse drying system for jaggery under forced convection mode. It concluded that the thermal model was approved with the experimental observations and numbers of air changes per hour, relative humidity, jaggery mass were effective parameters for drying of jaggery under forced convection mode [17].

Tiwari et al. studied experimentally, greenhouse drying (natural convection) of prawn. It predicted that the convective heat transfer coefficients as function of moisture content of prawn and due to size and initial moisture content of prawn, values of convective heat transfer coefficient diversed radically with size and the type of substances [18].Das and Tiwari performed convective heat transfer coefficient during greenhouse fish drying for prawn under forced convection mode. It concluded that in case of forced convection drying, moisture removed was quickly and more than the natural convection drying [19]. Shukla et al. performed an experimental study in a cascade greenhouse to see the effect of an inner thermal curtain in an evaporative cooling system [20]. Sethi and Arora did improvement in greenhouse solar drying using inclined north wall reflection under natural and forced convection mode. On the basis of results it concluded that inside greenhouse dryer, optimally inclined reflective north wall can appreciably increase the total solar radiation which is attendant onto the crop and it can further enhance both air and crop temperature of it under natural as well as forced convection mode of drying from 10 am to $2 \mathrm{pm}$ [21]. Janjai et al. presented a simulated and experimental performance of a PV-ventilated solar greenhouse dryer for drying of banana and peeled longan. Its result showed that the products dried in it are very high-quality dried product and significant reductions in drying time than open-air sun drying [22]. Ayyappan and Mayilsamy was developed solar tunnel dryer with thermal storage to test its presentation for copra drying. It concluded that for producing high quality copra, a natural convection solar tunnel dryer was more appropriate for the coconut farmers [23]. Nayak et al. presented testing and drying of mint by a hybrid photovoltaic-thermal (PVT) - based greenhouse dryer. The result showed that it's drying efficiency was calculated as $34.2 \%$ and net extenuation over the period was calculated as 140.97 tons and dried products having increased shelf life and total fat, protein, carbohydrates, ash, crude fiber and chlorophyll contents were highest in dried samples than fresh samples. It concluded that it was used for various herbal / medicinal applications [24]. Boonyasri et al. analyzed the performance and economic evaluation of greenhouse dryer for pork drying. It concluded that in open sun drying the moisture content was decreased from $210 \% \mathrm{db}$ to $70 \% \mathrm{db}$ in $320 \mathrm{~min}$ in view of greenhouse drying took only $260 \mathrm{~min}$ [25].

Sadodin and Kashani presented numerical analysis of a solar greenhouse tunnel drier for copra drying. The result showed that SGTD reduces copra's moisture from $52.2 \%$ to $8 \%$ in $55 \mathrm{~h}$ below full load conditions. On the basis of results it concluded that this type of dryer used in rural areas without electricity grids and estimated meed periods of this dryer for copra is about 2.3 years [26].Kumar et al. investigated the convective heat transfer coefficient of khoa in both greenhouse and open sun drying for forced and natural convection modes. It concluded that convective heat transfer coefficient inside greenhouse under natural mode was least than for other modes and it was higher for forced mode and it decreases as the day of drying upgrades to the next day [27]. Ganguly and Ghosh 
presented cooling and ventilation technologies which were applied to agricultural greenhouses. It concluded by identifying some important areas on which further research needs to be held [28]. Akinjiola and Balachandran showed mass-heater supplemented greenhouse dryer an adjustable technology for post- harvest preservation problems in developing countries. It concluded that greenhouse dryer having the quality of its design and difficult designs were not always possible or cost effective [29]. Janjai studied the development and dissemination of greenhouse type solar dryer for small-scale dried food industries. The result showed that assessed payback periods of greenhouse type solar dryer for tomato is about 0.65 years [30]. Janjai et al. gave performance evaluation of a greenhouse solar dryer of longan fruits drying. It was observed that drying air temperature varied due to which acceptable range and good quality dried longan fruits were obtained [31].Anil et al. presented an experimental analysis of greenhouse dryer under no-load conditions. It was concluded that drying rate of forced convection is efficient than natural convection by $31 \%$ because of relative humidity for forced convection is less than that of natural convection mode [32]. Kumar presented the effect of size of khoa on convective heat and mass transfer coefficients during natural convection mode. The results showed that convective heat and mass transfer coefficients decrease due to enhance in size of the khoa pieces [33]. Prakash and Kumar made an attempt for the forecast of mass jaggery drying inside the natural convection greenhouse dryer by the use of artificial neural network (ANN). It was concluded that ANN model became an effective tool for the prediction of hourly jaggery mass [34]. Rai et al. was presented an experimental study of drying in the forced convection mode. It was noticed that average convective heat transfer coefficient is prior for the forced convection greenhouse drying than the open sun drying mode [35].

Tanwanichkul et al. proposed thermal modeling of sandwich greenhouse drying system for rubber sheets under forced convection. It results showed that the moisture content can decrease from $36.4 \%$ to $2.8 \%$ in fewer than 2 days of the rubber sheets [36].Kumar performed an experimental study of vermicelli drying under natural convection mode. It was observed that on consecutive days, unlike values of convective heat transfer coefficients were received for dried such like vermicelli sample [37]. Nidhi presented vermicelli drying characteristics inside the slant height greenhouse dryer. It concluded that drying rate and moisture content on the dry basis (\%) is found to be falling with respect to increasing drying time [38]. The convective and evaporative heat transfer coefficients for papad underneath forced convection greenhouse drying mode were measured [39]. Results showed that the monsoon seasons were more unpredictable and in poorer drying conditions. Drying in active mode was suggested as more encouraging than passive mode due to controlling of relative humidity by an exhaust fan. A MATLAB-based modeling for drying of cocoa beans in the greenhouse solar dryer was developed [40]. It was observed that the greenhouse technology significantly improves the quality of the product and reduces the drying period.

Solar greenhouse dryers of different shapes have been consumed for drying of various products under distinct environmental conditions. Results of greenhouse under forced convection drying of different commodities are summarized in Table 2.1.

TABLE 2.1. Analysis of greenhouse drying under forced convection mode

\begin{tabular}{|c|c|c|c|l|}
\hline $\begin{array}{c}\text { S. } \\
\text { No. }\end{array}$ & Researcher & Year & $\begin{array}{c}\text { Agricultural } \\
\text { products \& } \\
\text { vegetables }\end{array}$ & \multicolumn{1}{|c|}{ Remarks } \\
\hline 1. & $\begin{array}{c}\text { Condori and } \\
\text { Saravia }\end{array}$ & 1998 & Sweet pepper & $\begin{array}{l}\text { Presented two different types greenhouse drier under } \\
\text { forced convection mode. }\end{array}$ \\
\hline 2. & $\begin{array}{c}\text { Condori and } \\
\text { Saravia }\end{array}$ & 2003 & Sweet pepper & $\begin{array}{l}\text { Presented an analytical tunnel greenhouse dryer } \\
\text { under forced convection mode. }\end{array}$ \\
\hline 3. & Jain and Tiwari & 2004 & Cabbage and peas & $\begin{array}{l}\text { The convective mass transfer coefficient was double } \\
\text { in greenhouse dryer under the forced mode than } \\
\text { the natural mode. }\end{array}$ \\
\hline 4. & Tiwari et al. & 2004 & Jaggery & $\begin{array}{l}\text { The moisture removal rate was lower in forced } \\
\text { convection mode than the natural convection mode } \\
\text { due to low drying temperature. }\end{array}$ \\
\hline 5. & Das and Tiwari & 2008 & Fish & $\begin{array}{l}\text { The convective heat transfer coefficient were } \\
\text { superior for forced convection than the natural } \\
\text { convection drying. }\end{array}$ \\
\hline 6. & Sethi and Arora & 2009 & Bitter gourd & The moisture content was maintained up to 7\%. \\
\hline
\end{tabular}


IOSR Journal of Mechanical and Civil Engineering (IOSR-JMCE) e-ISSN: 2278-1684, p-ISSN: 2320-334X

\begin{tabular}{|c|c|c|c|c|}
\hline 7. & Janjai et al. & 2009 & Longan and bananas & The payback period was estimated to be 2.3 years. \\
\hline 8. & Kumar et al. & 2011 & Khoa & $\begin{array}{l}\text { The values of convective heat transfer coefficients } \\
\text { were reported to be } 0.86-1.09 \mathrm{~W} / \mathrm{m}^{2}{ }^{\circ} \mathrm{C} \text {. }\end{array}$ \\
\hline 9. & Kumar & 2013 & Papad & $\begin{array}{l}\text { The convective and evaporative heat transfer } \\
\text { coefficients for papad were reported from } 0.759 \text { to } \\
23.48 \mathrm{~W} / \mathrm{m}^{2}{ }^{\circ} \mathrm{C} \text { respectively. }\end{array}$ \\
\hline 10. & Rai et al. & 2013 & $\begin{array}{l}\text { Bitter melon } \\
\text { (karalla) }\end{array}$ & $\begin{array}{l}\text { The maximum values of convective heat transfer } \\
\text { coefficients were reported to be } 3.67323 \mathrm{~W} / \mathrm{m}^{2}{ }^{\circ} \mathrm{C} \text {. }\end{array}$ \\
\hline 11. & $\begin{array}{c}\text { Manoj and } \\
\text { Manivannan }\end{array}$ & 2013 & $\begin{array}{l}\text { Cocoa } \\
\text { beans }\end{array}$ & Moisture content was maintained upto $7 \% \mathrm{db}$. \\
\hline 12. & Prakash and Kumar & 2014 & Review & $\begin{array}{l}\text { Designs, construction and working principles of } \\
\text { different greenhouse dryer under active and passive } \\
\text { modes. }\end{array}$ \\
\hline 13. & Sahdev & 2014 & Review & $\begin{array}{l}\text { Designs, construction and working principles of } \\
\text { different greenhouse and open sun drying method. }\end{array}$ \\
\hline 14. & Nidhi & 2015 & Vermicelli & $\begin{array}{l}\text { Presented drying characteristics of vermicelli in a } \\
\text { slant height greenhouse dryer. }\end{array}$ \\
\hline
\end{tabular}

\section{CONCLUSION}

Utilization of greenhouse drying in instead of open sun drying increased the product quality and prevents spoilage. From the literature, following conclusions have been drawn:

1. Drying rate is faster under forced convection than natural convection mode.

2. Convective heat transfer coefficient is more than open sun drying mode.

3. Values of convective heat transfer coefficient diverse with the size and primary moisture content of a product.

4. Use of inclined reflection north wall in greenhouse solar drying can increased the total solar radiation.

5. PV- ventilated solar greenhouse dryer gives a very high quality dried product and reduces drying time than open air sun drying.

6. For coconut farmers, natural convection solar tunnel dryer is more suitable.

7. Greenhouse drying reduces moisture content in a very less time.

8. Solar greenhouse tunnel drier can be used in rural areas.

9. Relative humidity under forced convection is inferior to natural convection mode.

10. Greenhouse type agricultural dryers are of much higher quality and more effective than open sun dryers.

\section{REFERENCE}

[1] R. K. Sahdev, Open sun and greenhouse drying of agricultural and food products: A Review, International Journal of Engineering Research \& Technology, 3, 2014, 2278-0181.

[2] O. Prakash, Anil Kumar, Solar greenhouse drying: A review, Renewable and sustainable energy review, 29, 2014, 905-910.

[3] R.K. Behl, R.N. Chhibar, S.Jain, V.P.Bahl, N.EIBassam, Renewable energy sources and their applications, International journal, 2013.

[4] Odesola, I.F. and Ezekwem, Chidozie, The effect of shape and orientation on a greenhouse: A review, an international journal of science and technology, 1, 2012, 2225-8612.

[5] M. Liu, S. Wang, K. Li, Study of the solar energy drying device and its application in traditional Chinese medicine in drying, International journal of clinical medicine, 6, 2015, 271-280.

[6] M. Condori, L. Saravia, The performance of forced convection greenhouse driers, Renewable energy, 13, 1998, 453-469.

[7] S. Wang, T. Boulard, R. Haxaire, Measurement and analysis of air speed distribution in a naturally ventilated greenhouse, International society for horticultural science, 2000.

[8] M. Condori, L. Saravia, Analytical model for the performance of the tunnel- type greenhouse drier, Renewable energy, 28, 2003, 467-485.

[9] Farhat, S. Kooli, C. Kerkeni, M. Maalej, A. Fadhel, A. Belghith, Validation of a pepper drying model in a polyethylene tunnel greenhouse, International journal of thermal sciences, 43, 2004, 53-58.

[10] D. Jain, G.N. Tiwari, Effect of greenhouse on crop drying under natural and forced convection 1: Evaluation of convective mass transfer coefficient, Energy conversion and management, 45, 2004, 765-783.

[11] G.N. Tiwari, S. Kumar, O. Prakash, Evaluation of convective mass transfer coefficient during drying of jaggery, Journal of food engineering, 63, 2004, 219-227.

[12] D. Jain, G.N.Tiwari, Effect of greenhouse on crop drying under natural and forced convection 2. Thermal modeling and experimental validation, Energy conversion and management, 45, 2004, 2777-2793. 
[13] D. Jain, Modeling the performance of greenhouse with packed bed thermal storage on crop drying application, Journal of food engineering, 71, 2005, 170-178.

[14] T. Koyuncu, An investigation on the performance improvement of greenhouse-type agricultural dryers, Renewable energy, 31, 2006, 10551071.

[15] S. Janjai, C. Chaichoet, P. Intawee, Performance of a PV-ventilated greenhouse dryer for drying bananas, Asian journal on energy and environment, 2005.

[16] Kumar, G.N. Tiwari, Effect of mass on convective heat transfer coefficient during onion flakes drying, American journal of food technology, 1, 2006, 1557-4571.

[17] Kumar, G.N. Tiwari, Thermal modeling and parametric study of a forced convection greenhouse drying system for jaggery : An experimental validation, International journal of agricultural research, 2006, 1816-4897.

[18] G.N. Tiwari, T. Das, B. Sarkar, Experimental study of greenhouse prawn drying under natural convection, International commission of agricultural engineering, 8, 2006.

[19] T. Das, G.N. Tiwari, Heat and mass transfer of greenhouse fish drying under forced convection mode, International journal of agricultural research, 2008, 1816-4897.

[20] Shukla, G.N. Tiwari, M.S. Sodha, Experimental study of effect of an inner thermal curtain in evaporative cooling system of a cascade greenhouse, Solar energy, 82, 2008, 61-72.

[21] V.P.Sethi, S. Arora, Improvement in greenhouse solar drying using inclined north wall reflection, solarenergy, 83, 2009, $1472-1484$.

[22] S. Janjai, N. Lamlert, P. Intawee, B. Mahayothee, B.K. Bala, M. Nagle, J. Muller, Experimental and simulated performance of a PVventilated solar greenhouse dryer for drying of peeled longan and banana, Solar energy, 83, 2009, 1550-1565.

[23] S. Ayyappan, Dr. K. Mayilsamy, Solar tunnel drier with thermal storage for drying of copra, International journal of energy technology and policy, 2010.

[24] S. Nayak, A. Kumar, J. Mishra, G.N. Tiwari, Drying and testing of mint (Mentha piperita) by a hybrid photovoltaic-thermal (PVT)- Based greenhouse dryer, Drying technology, 29, 2011, 0737-3937.

[25] M. Boonyasri, C. Lertsatitthanakorn, L. Wiset, N. Poomsa-ad, Performance analysis and economic evaluation of a greenhouse dryer for pork drying, KKU Engineering journal, 38, 2011, 433-442.

[26] S. Sadodin, T. T. Kashani, Numerical investigation of a solar greenhouse tunnel drier for drying of copra, Cornell university library, 2011.

[27] M. Kumar, K. S. Kasana, S. Kumar, O. Prakash, Experimental investigation on convective heat transfer coefficient for khoa drying, International journal of current research, 3, 2011, 0975-833X.

[28] AGanguly, S. Ghosh, A review of ventilation and cooling technologies in agricultural greenhouse application, Iranica journal of energy and environment, 2011, 2079-2115.

[29] O. P. Akinjiola, U. Balachandran, Mass- heater supplemented greenhouse dryer for post-harvest preservation in developing countries, Journal of sustainable development, 5, 2012, 1913-9063.

[30] S. Janjai, A greenhouse type solar dryer for small-scale dried food industries: Development and dissemination, International journal of energy and environment, 3, 2012, 2076-2895.

[31] S. Janjai, P. Intawee, B. Mahayothee, P. Sruamsiri, E. Khajornpaisan, A. Sangjaroen, Y. Boonrod, B. K. Bala, M. Precoppe, M. Nagle, J. Muller, Performance evaluation of a greenhouse solar dryer for drying longan fruits, International conference, Germany, 2012.

[32] K. Anil, P. Om, K. Ajay, T. Abhishek, Experimental analysis of greenhouse dryer in no-load conditions, Journal of environment research and development, 7, 2013.

[33] M. Kumar, Effect of size on the convective heat and mass transfer coefficients during natural convection greenhouse drying of khoa- A Heat desiccated milk product, International journal of renewable energy and biofuels, 2014.

[34] O. Prakash, A. Kumar, Application of artificial neural network for the prediction of jaggery mass during drying inside the natural convection greenhouse dryer, International journal of ambient energy, 2013

[35] AK. Rai, S. A. Idrisi, S. Ahmad, An experimental study of forced convection greenhouse drying, International journal of advanced research in engineering and technology, 4, 2013, 0976-6499.

[36] B. Tanwanichkul, S. Thepa, W. Rordprapat, Thermal modeling of the forced convection sandwich greenhouse drying system for rubber sheets, Energy conversion and management, 74, 2013, 511-523.

[37] P. Kumar, Natural convection greenhouse drying of vermicelli: An experimental study, International journal of research in aeronautical and mechanical engineering, 2, 2014, 64-80.

[38] Nidhi, Drying characteristics of vermicelli in a slant height greenhouse dryer, ISOR journal of mechanical and civil engineering, 2015.

[39] M. Kumar Forced Convection Greenhouse Papad Drying: an Experimental Study, Journal of Engineering Science and Technology, 8, 2, $2013,177-189$.

[40] M. Manoj, and A. Manivannan, Simulation of Solar Dryer Utilizing Greenhouse Effect For Cocoa Bean Drying, International Journal of Advanced Engineering Technology, 4, 2, 2013, 24-27. 